\title{
Atopy in Children and Adolescents with Familial Mediterranean Fever
}

\author{
Ailesel Akdeniz Ateșli Çocuk ve Adolesanlarda Atopi
}

\author{
Chousein Amet, Nilgün Selçuk Duru, Murat Elevli, Mahmut Çivilibal \\ Haseki Training and Research Hospital, Clinic of Pediatrics, Istanbul, Turkey
}

\begin{abstract}
Aim: To investigate the frequency of atopic disease, a prototype Th2 disease in patients with familial Mediterranean fever (FMF).

Materials and Methods: This study included 49 children with FMF and 30 age-and gender-matched healthy children. All participants were questioned about allergic diseases using the modified questions from ISAAC Study questionnaire. Total immunoglobulin (Ig) E levels and eosinophil counts were determined, and skin-prick test was performed.

Results: The skin-prick test showed no significant difference in the rate of positive response to at least one allergen in the children with $\mathrm{FMF}(10.2 \%)$ and the control group $(10.0 \%)$. The rate of physician-diagnosed asthma, allergic rhinitis and eczema were similar in both groups. The answers given to the questions about allergic diseases were similar and there was no difference in the measurements of $\mathrm{lg}$ E levels and eosinophil counts of the two groups. Conclusion: We determined that atopy frequencies were similar in children with and without FMF.

Key Words: Atopy, allergy, autoimmune, autoinflammatory, familial Mediterranean fever
\end{abstract}

\section{ÖZET}

Amaç: Ailesel Akdeniz ateşli (AAA) hastalarda Th2 hastalıkların bir prototipi olarak atopik hastalık sıklığını araştırmak.

Gereç ve Yöntemler: Çalışmaya 49 AAA'lı çocuk ve onlar ile aynı yaş ve cinsiyette 30 sağlam çocuk alındı. Bütün katıımcılar modifiye edilmiş ISAAC anket formu kullanılarak sorgulandı. Toplam Immünglobulin (Ig) E düzeyleri ve eozinofil sayıları belirlendi ve deri prik testleri yapıldı.

Bulgular: Deri prik testinde en az bir alerjene pozitif yanıt hızı AAA'lı çocuklarda $(\% 10,2)$ ve kontrol grubunda $(\% 10,0)$ istatistiksel olarak anlamlı farklı değildi. Her iki grupta doktor tanıı astım, alerjik rinit ve egzema sıkığı benzer bulundu. Iki grup arasında alerjik hastalıklar hakkındaki soruların yanıtları, lgE düzey ölçümleri ve eozinofil sayıları farklı bulunmadı.

Sonuç: Çalışmamızda atopi sıkığı acısından AAA'lı çocuklar ve sağlıkı kontroller arasında anlamlı bir farkılık saptanmadı.

Anahtar Kelimeler: Atopi, alerji, otoimmün, otoenflamatuvar, ailesel Akdeniz ateşi

\section{Introduction}

Familial Mediterranean fever (FMF) is an autoinflammatory disease caused by mutations in MEFV, a gene which encodes pyrin and localizes on the short arm of chromosome 16p13. Mutations in the MEFV lead to uncontrolled neutrophil activation and cause the autoinflammatory phenotype of FMF (1-3). It mainly occurs in populations from the Mediterranean basin, mainly Turks, Levantine Arabs, Sephardic Jews, Druze, and Armenians $(4,5)$.
Atopic disorders comprise allergic asthma, allergic rhinitis and atopic eczema. The atopic state is determined by skin-prick tests to common allergens, by the presence of allergen-specific $\lg E$ in their serum, and by the elevation of the total serum $\lg E$ (6). The pathogenic features of atopic disorders are elevated levels of $\lg \mathrm{E}$ and a characteristic $\mathrm{T}$ helper cell cytokine pattern. It has been reported that the cytokine pattern of autoimmune and inflammatory diseases is Th1 pattern, whereas that of atopic disorders is Th2 $(7,8)$. The Th1/Th2 antagonism suggests that the prevalence of atopy should be decreased in autoimmune and inflammatory 
disease. However, new $\mathrm{T}$ cell helper groups have been described recently, and it has been reported that Th 17 is more effective than Th1 on especially autoimmune and inflammatory illness (9).

The aim of this study was to determine whether or not an inverse relationship existed between atopic disease with a Th2 response and FMF.

\section{Materials and Methods}

The study was approved by the local Ethics Committee and was conducted in accordance with the guidelines proposed in the Helsinki Declaration. Informed consent forms were obtained from children (older than 12 years of age) and/or legal guardians.

\section{Patients}

Forty-nine FMF patients and 30 gender-matched healthy controls were enrolled in the study. A questionnaire about allergic asthma, allergic rhinitis and eczema was filled by the patients and the healthy control group. The questionnaire was modified from The International Study of Asthma and Allergies in Childhood (ISAAC), previously translated into Turkish (10). Skin-prick test was done to all the children, their eosinophil counts and total IgE levels were determined. Children with any chronic disease and acute infection were excluded from the study. All FMF patients were on Colchicine and in attack free period. All cases were clinically interviewed. Additionally, MEFV gene mutations of patients were taken from medical records.

\section{Skin-prick Tests}

Skin-prick tests for aeroallergens were performed on all children with 28 common aeroallergens belonging to 7 groups; house dust mites (dermatophagoides farinae, dermatophagoides pteronyssinus), trees I (alder, corylus, papulus, ulmus, salix), trees II (betula verrucosa, fagus silvitica, quercus robur, platanus orientalis), herbs (artemisia vulgaris, urtica diocia, taraxacum vulgare, plantago lanceolata), mixture of grasses (holcus lanatus, dactylis glomerata, lolium perene, phleum pretense, poa pratensis, festuca pratensis), animal epithelia (cat hair, dog hair and sheepwool) and cereals (barley, oat, rye, wheat) (Allergopharma, Hamburg, Germany). Histamine and saline were used as positive and negative controls, respectively.

A drop of each allergen extract was placed on the volar surface of the left forearm and was penetrated with a staller point. After 15 minutes, the wheal reaction was measured as the mean of the longest diameter and the diameter perpendicular to it. A wheal response $\geq 3 \mathrm{~mm}$ than the negative control with surrounding erythema was considered positive. Atopy was defined as the presence of at least one positive reaction to these allergens.

\section{Eosinophil Counts}

The peripheral blood eosinophil was counted in blood samples containing EDTA using an automated hematology analyzer (Pentra DX 120). Blood sampling of all subjects was performed at the same time daily to avoid diurnal variation of eosinophil count. Eosinophilia was defined as an eosinophil count $>300$ cells per microliter.

\section{Serum $\lg E$}

Total IgE levels were measured by Architect ci1600 (Abbott, Barcelona, Spain). Normal serum IgE levels are given by the manufacturer as $<15 \mathrm{IU} / \mathrm{ml}$ for age $1-12$ months, $<60$ $\mathrm{IU} / \mathrm{ml}$ for $1-5$ years, $<90 \mathrm{IU} / \mathrm{ml}$ for $6-9$ years, and $<200 \mathrm{IU} /$ $\mathrm{ml}$ for 10-15 years. IgE levels above the age specific normal range will be referred to as 'elevated' lgE from here on.

\section{Statistical Analysis}

All statistical analyses were performed using computer software (SPSS for Windows version 20.0). For the tests of normality, we used Kolmogorov-Smirnov test for nominal variables. Continuous variables were compared by oneway analysis of variance (ANOVA), Student's t-test, MannWhitney-U or Kruskal-Wallis according to distribution of values. Chi-square test or Fisher's exact test for comparison of qualitative data were used in the evaluation of results. Statistical significance was determined as $p<0.05$.

\section{Results}

There was no significant difference in age and sex between FMF patients and controls. The mean age was $11.8 \pm 3.1$ years and $12.6 \pm 3.0$ years, respectively (Table I). Mean age at the onset of the symptoms was $6 \pm 3.65$ years (min-max. $=1-13$ ), mean age of diagnosis was detected as 8,37 $\pm 3,36$ years (min-max. $=3-15$ ).

The most common MEFV variant patterns seen were homozygous of M694V (24.5\%), heterozygous of E1480 (16.6\%) and heterozygous of M694V (12.2\%). Fifteen of the children, the homozygous variants of MEFV (13 patients: M694V/M694V, one patient: M680I/M680I, one patient: M697V/M697V) were found. In the rest of the patients, the heterozygous and compound heterozygous (8 patients: E148Q, 6 patients: M694V, 4 patients: M694V, 2 patients: F479L/M694V, 2 patients: M694VN726A, 1 patient: A744S, 1, 1 patient: 680I/M694V, 1 patient: M694I, 1 patient: M694V, 1 patient: M680I, 1 patient: V726A, 1 patient: E 148Q/M694V, 1 patient: P369S) were found. The minor variant, R202Q, was detected in 2 patients (Table II).

The rate of physician-diagnosed asthma, allergic rhinitis and atopic dermatitis were similar in both groups. There was no difference between the 2 groups based on the answers of other questions about asthma allergic rhinitis, and atopic dermatitis (Table II).

In the study group, Eosinophilia was detected in 3 and elevation of serum $\lg E$ was detected in 8 patients. In the control group, eosinophilia was not observed while elevation of serum IgE was observed in 4 children. No difference in blood eosinophilia and elevation of serum IgE was observed between children with FMF and healthy children ( $p>0.05)$ (Table III).

Five children in the study group and 3 in the control group were found to be positive in at least one skin-prick test to allergens that included mixture of grasses, cereals, mites and 
animal epithelia. The most common allergen noted by skinprick test was house dust mites. Others were occasionally positive. There was no significant difference in skin-prick test between the groups ( $p>0.05$ ) (Table III).

\section{Discussion}

In this study, we investigated the frequency of allergic disease in children with FMF, an autoinflammatory disease. Skin-prick test positivity, elevation of $\lg E$ levels and eosinophilia were not significantly different in children with FMF and the control group.

Until now, only two studies investigating the relationship between atopy and FMF have been published. In the first of these studies, Sackesen et al. (11) reported that the prevalence of atopy (6.7\%) in patients with FMF was significantly lower than that in healthy children (20.6\%). However, in this study, the mean serum total lgE level counts did not differ between the groups, similar to our study. Eosinophil counts between the groups were not compared in this study. Recently, a second study examining the frequency of atopy in patients with Behçet disease and FMF has been published. In the FMF patients, positivity to skin-prick test was lower than the control group but the results were not statistically significant (12). Similar to our study, the mean serum total IgE level and eosinophil counts did not differ between the groups. However, this study was different from ours in that it was performed on adult patients.

What triggers the inflammation in FMF has not been clarified yet. Autoinflammatory diseases are associated with an inability to control inflammation caused by primary dysfunction of members of the innate immune system, such as neutrophils and monocytes/macrophages. FMF is caused by mutations in the MEFV gene, encoding pyrin, which is known to regulate the inflammasome, a platform for processing interleukin (IL)-1 $\beta$ (13).

Cytokines are important in health and disease, specifically in host responses to infection, immune responses, inflammation, trauma, and cancer. The $T$ helper cells are a type of $\mathrm{T}$ cell that play an important role in the immune system. Th1 type cells heavily produce inflammatory cytokine interferon (IFN) $\gamma$ and induce the cellular immune response, while Th2 type cells heavily produce anti-inflammatory cytokine IL-4, IL-5, IL-13 and induce the humoral immune response (8). Th1 and Th2 are mutually inhibitory and show regulatory properties. They regulate the development and function of each other, and thus create a balance between the two types of cells. Th2 cells have been

Table I. Demographic characteristics of the patients with familial Mediterranean fever and controls

\begin{tabular}{|l|l|l|l|}
\hline & FMF (+) $\mathbf{n = 4 9}$ & FMF $(-) \mathbf{n = 3 0}$ & $\mathbf{p}$ \\
\hline Age (years) & $11.8 \pm 3.1$ & $12.6 \pm 3.0$ & 0.289 \\
\hline Gender (boy/girl) & $22 / 27$ & $13 / 17$ & 0.892 \\
\hline
\end{tabular}

FMF: Familial Mediterranean fever recognized as inducing bronchial asthma, whereas Th1 cells trigger autoimmune and inflammatory diseases $(7,8)$. Until recently, a lot of pathological conditions such as allergic and autoimmune diseases were based on the disruption of this balance. A few papers reported that FMF was driven by Th1 response $(14,15)$.

\begin{tabular}{|l|l|l|l|}
\hline \multicolumn{4}{|l|}{ Table II. Summary of modified International Study of Asthma and } \\
Allergies in Childhood questionnaire data and MEFV gene mutations \\
\hline & $\begin{array}{l}\text { FMF (+) } \\
\text { n (\%) }\end{array}$ & $\begin{array}{l}\text { FMF (-) } \\
\text { n (\%) }\end{array}$ & p \\
\hline Responses for asthma & & & \\
\hline History of current wheezing & $4(8.2)$ & $0(0)$ & 0.292 \\
\hline History of ever wheezing & $4(8.2)$ & $0(0)$ & 0.292 \\
\hline Doctor diagnosed asthma & $2(4)$ & $0(0)$ & 0.523 \\
\hline Responses for allergic rhinitis & & & \\
\hline Doctor diagnosed allergic rhinitis & $2(4)$ & $1(3.3)$ & 1 \\
\hline Lifetimes rhinitis & $6(12)$ & $1(3.3)$ & 0.243 \\
\hline Associated itchy eye & $6(12)$ & $1(3.3)$ & 0.243 \\
\hline Responses for eczema & & & \\
\hline Doctor diagnosed atopic dermatitis & $0(0)$ & $0(0)$ & \\
\hline Chronic rash & $0(0)$ & $0(0)$ & \\
\hline MEFV mutations & & & \\
\hline M694V/M694V & $1(2)$ & & \\
\hline E1480 & $13(25.6)$ & & \\
\hline M694V & $8(16.3)$ & & \\
\hline M694V & $6(12.2)$ & & \\
\hline F479L/M694V & $4(8.2)$ & & \\
\hline M694V/V726A, & $2(4.1)$ & & \\
\hline M680I/M680I, & $2(4.1)$ & & \\
\hline M697V/M697V & $1(2)$ & & \\
\hline A744S & $1(2)$ & & \\
\hline 680I/M694V & $1(2)$ & & \\
\hline M694I & $1(2)$ & & \\
\hline M694V & & & \\
\hline
\end{tabular}

FMF: Familial Mediterranean fever

Table III. Comparison of the numbers of children with prick test positive, eosinophilia and elevated IgE levels

\begin{tabular}{|l|l|l|l|}
\hline & $\begin{array}{l}\text { FMF (+) } \\
\mathbf{n}(\%)\end{array}$ & $\begin{array}{l}\text { FMF (-) } \\
\mathbf{n}(\%)\end{array}$ & $\mathbf{p}$ \\
\hline Prick test positive & $5(10.2)$ & $3(10)$ & 1.000 \\
\hline Eosinophilia & $3(6)$ & $0(0)$ & 0.284 \\
\hline Elevated IgE levels & $8(16)$ & $4(13)$ & 0.501 \\
\hline
\end{tabular}

FMF: Familial Mediterranean fever 
In our study, the prevalence of atopy investigated by skinprick test, serum IgE levels and eosinophil count in patients with FMF were similar to those in healthy controls. This finding is contrary to the opinion of the traditional inverse correlation between atopy and autoimmunity and inflammatory disease. Therefore, we suggest that FMF is different from Th1 type autoimmune disease or Th1 response.

\section{Conclusion}

Our results did not show antagonistic a relationship between FMF and atopic diseases driven by Th2 response. Further studies with a larger number of patients are necessary to determine the predominant cytokine profile in patients with FMF.

Disclosure: Authors have no conflict of interest, and the work was not supported or funded by any drug company, Ethics Committee Approval: The study design was approved by ethics committee of Haseki Training and Research (2009; Protocol No: 12-21/01/2009), Informed Consent: All participants gave a written informed consent for participation in the study, Concept: Nilgün Selçuk Duru, Murat Elevli, Mahmut Çivilibal, Design: Nilgün Selçuk Duru, Murat Elevli, Mahmut Çivilibal, Data Collection or Processing: Chousein Amet, Nilgün Selçuk Duru, Analysis or Interpretation: Nilgün Selçuk Duru, Murat Elevli, Mahmut Çivilibal, Literature Search: Chousein Amet, Nilgün Selçuk Duru, Writing: Nilgün Selçuk Duru, Peer-review: Externally peer-reviewed, Conflict of Interest: No conflict of interest was declared by the authors, Financial Disclosure: There was no financial support.

\section{References}

1. French FMF Consortium. A candidate gene for familial Mediterranean fever. Nat Genet 1997; 17:25-31.

2. Centola $M$, Wood $G$, Frucht DM, Galon J, Aringer $M$, Farrell $\mathrm{C}$, et al. The gene for familial Mediterranean fever, $M E F V$, is expressed in early leukocyte development and is regulated in response to inflammatory mediators. Blood 2000; 95:3223-31.
3. Sood R, Blake T, Aksentijevich I, Wood G, Chen X, Gardner $\mathrm{D}$, et al. Construction of a 1-Mb restriction-mapped cosmid contig containing the candidate region for the familial Mediterranean fever locus (MEFV) on chromosome 16p 13.3. Genomics 1997; 42:83-95.

4. Ben-Chetrit E, Levy M. Familial Mediterrenean fever Lancet 1998; 351: 659-64.

5. Sahin S, Yalcin I, Senel S, Ataseven H, Uslu A, Yildirim O, et al. Assesment life quality of familial Mediterranean fever patients by short form-36 and its relationship with disease parameters. Eur Rev Med Pharmacol Sci 2013; 17:958-63.

6. Johansson SG, Bieber T, Dahl R, Friedmann PS, Lanier BQ, Lockey RF, et al. Revised nomenclature for allergy for global use: Report of the Nomenclature Review Committee of the World Allergy Organization, October 2003. J Allergy Clin Immunol 2004; 113:832-6.

7. Rudwaleit M, Andermann B, Alten R, Sörensen H, Listing J, Zink $A$, et al. Atopic disorders in ankylosing spondylitis and rheumatoid arthritis. Ann Rheum Dis 2002; 261:968-74.

8. Gazit V, Tasher D, Hanukoglu A, Landau Z, Ben-Yehuda Y, Somekh $\mathrm{E}$, et al. Atopy in children and adolescents with insulin-dependent diabetes mellitus. Isr Med Assoc J 2008; 10:858-61.

9. Langrish $\mathrm{CL}$, Chen $\mathrm{Y}$, Blumenschein WM, Mattson J, Basham B, Sedgwick JD, et al. IL-23 drives a pathogenic T cell population that induces autoimmune inflammation. $J$ Exp Med 2005; 201:233-40.

10. Oneş U, Sapan N, Somer A, Dişçi R, Salman N, Güler N, et al. Prevalence of childhood asthma in Istanbul, Turkey. Allergy 1997; 52:570-5.

11. Sackesen C, Bakkaloglu A, Sekerel BE, Ozaltin F, Besbas N, Yilmaz $E$, et al. Decreased prevalence of atopy in paediatric patients with familial Mediterranean fever. Ann Rheum Dis 2004; 63:187-90.

12. Yazici A, Orge Gonullu E, Kardes B, Cefle A. The prevalence of atopy in patients with familial Mediterranean fever and Behçet's disease. Clin Exp Rheumatol 2013; 31:68-70.

13. Sugiyama R, Agematsu K, Migita K, et al. Defect of suppression of inflammasome-independent interleukin-8 secretion from SW982 synovial sarcoma cells by familial Mediterranean fever-derived pyrin mutations. Mol Biol Rep 2014; 41:545-53. doi: 10.1007/s11033-013-2890-y

14. Simsek I, Pay S, Pekel A, et al. Serum proinflammatory cytokines directing $T$ helper 1 polarization in patients with familial Mediterranean fever. Rheumatol Int 2007; 27:807-11.

15. Aypar E, Ozen S, Okur H, Kutluk T, Besbas N, Bakkaloglu A. Th1 polarization in familial Mediterranean fever. J Rheumatol 2003; 30:2011-3. 